\title{
K-12 Student Perceptions of Online Teacher and On-site Facilitator Support in Supplemental Online Courses
}

\author{
Jered Borup and Chawanna B. Chambers \\ George Mason University \\ Rebecca Stimson \\ Michigan Virtual
}

\begin{abstract}
In an attempt to better support their students and reduce online course attrition rates, some brickand-mortar K-12 schools provide their online students with an on-site facilitator who supports students face-to-face. However, little is known about how students perceive the support provided by their on-site facilitator and online teacher. For this report, 70 students completed a survey and 51 students participated in one of eight focus groups to share their perceptions and experiences regarding online teacher and on-site facilitator support. Findings focused on the following support indicators: (1) advising students regarding course enrollments, (2) orienting students to online learning procedures and expectations, (3) facilitating interactions, (4) developing caring relationships, (5) motivating students to more fully engage in learning activities, (6) organizing and managing student learning, and (7) instructing students regarding the course content. The majority of support appeared to come from students' on-site facilitators. An important exception was that the large majority of the content-related support came from the online teacher. While students were largely positive when describing the support from their on-site facilitators, students were split and more critical of the support (or the lack of support) from their online teacher.
\end{abstract}

Keywords: parental engagement, online learning, student engagement, virtual schooling, online teachers, on-site facilitators

Borup, J., Chambers, C.B., \& Stimson, R. (2019). K-12 student perceptions of online teacher and on-site facilitator support in supplemental online courses. Online Learning, 23(4), 253280. doi:10.24059/olj.v23i4.1565

\section{K-12 Student Perceptions of Online Teacher and On-site Facilitator Support in Supplemental Online Courses}

The growth in K-12 online course enrollments has increased the need for highly skilled online teachers (Evergreen Education Group, 2017). Teacher preparation programs have largely failed to address the skills that are unique to K-12 online teaching and those teachers who begin teaching online commonly lack the ability to fully support and engage with students (Archambault, Kennedy, Shelton, Dalal, McAllister, \& Huyett, 2016). The skills that teachers require can also vary based on their model of online learning. While exact numbers are difficult to ascertain, it is clear that the majority of students who enroll in online courses do so to supplement face-to-face 
courses (Evergreen Education Group, 2017). Some of the largest supplemental online course providers are state-run virtual schools. Evergreen Education Group (2017) estimated that in 2016 over 523,000 students (84.39\% in high school) in 24 states enrolled in about 935,000 courses offered by state-run virtual programs.

Online courses have experienced significantly higher student attrition rates compared to their face-to-face counterparts. For instance, Freidhoff (2018) compared K-12 students' supplemental online course pass rates to those same students' pass rates in face-to-face courses in the state of Michigan. On average, Michigan students only passed 55\% of the over 500,000 online enrollments compared to a pass rate of $78 \%$ in their face-to-face courses. While students' failure to pass online courses is a complex issue with many possible causes, students often lack the necessary self-regulation ability and understanding of how to successfully learn online (Cavanaugh, 2007; Moore, 1993, 2007; Rice, 2006; Weil et al., 2013). Lowes and Lin (2015) summarized that online courses are especially challenging for adolescents because "students not only need to learn a subject online but need to learn how to learn online" (p. 18). While some have argued that unprepared students should be excluded from online learning, Rose, Smith, Johnson, and Glick (2015) stressed that online programs should take a more equitable approach to online learning: "Rather than 'Is online learning right for me?' students should be asked, 'What support systems do you need to be successful in online learning?"” (p. 75).

Research has found K-12 online teachers can provide a high degree of support that builds close, caring relationships with some students (Velasquez, Graham, \& Osguthorpe, 2013). However, supplemental courses rely heavily (if not exclusively) on asynchronous communication, making it difficult for online teachers to provide all of their students with the timely support they require (Rice \& Carter, 2016). As a result, online students are increasingly being provided with an on-site facilitator who works with them in their local brick-and-mortar schools. Similar to online teachers, on-site facilitators often lack professional development opportunities. One obstacle to providing professional development is the lack of research examining successful on-site facilitator and online teacher support. As the primary stakeholders, student perceptions can prove especially helpful to those wishing to better understand the types of support that are especially helpful to online students. While some researchers have examined K-12 online students' perceptions (see Roblyer, Freeman, Stabler, \& Schneidmiler, 2007), most research has ignored students' perceptions when examining student support in programs that offer students an online teacher and an on-site facilitator (Borup, 2018).

In this research, online high school students completed a survey and participated in focus groups to share how they perceived and valued the support they received from their online teachers and on-site facilitators. More specifically, this research addressed the following questions:

1. What types of support indicators do online students perceive while enrolled in a supplemental online course?

2. How do students value the support they receive from online teachers and on-site facilitators? 


\section{Review of Literature}

This section first reviews frameworks focused on online learning interactions and support in both higher education and K-12 settings. Following, research will be reviewed that has helped to identify the specific responsibilities of K-12 on-site facilitators.

\section{Online Learning Interaction and Support Frameworks}

Two frameworks that were developed in higher education are particularly relevant to K-12 online learning support because they focus on student interactions. In his Theory of Transactional Distance, Moore (1980) defined dialogue as two-way, mediated communication between the learner and instructor in a distance education setting. He also defined structure as the extent that learning objectives, procedures, and assessments are planned and cannot be easily adapted to students' needs. He then explained that courses with less structure can allow or require more dialogue. Inversely, courses with high structure are unable to respond to individual student's needs and require less dialogue. Moore also argued that the levels of dialogue and structure determine what he termed learner's transactional distance. Moore hypothesized that transactional distance is lowest in courses with high levels of dialogue and low structure and is the highest in courses with low levels of dialogue and high structure. Moore (2007) also explained that instructors need to carefully examine learner autonomy, or the ability to decide "what to learn, how to learn, and how much to learn" (p. 90). Moore (1980) warned that "a learner cannot learn effectively if the educational transaction demands more autonomy than he is able to exercise" (p. 29). Moore (2007) later explained "the greater the transactional distance the more the learners have to exercise autonomy" (p. 95). Moore (1993) also highlighted the subjective nature of transactional distance when he stated that it was a "psychological and communications space" (p. 22) that can even be present in face-to-face education. Garrison (2009) made the distinction between distance education that focuses on principles of independence, autonomy, and self-pacing, and online learning that focuses on principles of collaborative constructivist approaches. Using social constructivist principles, Garrison and his colleagues (Garrison, Anderson, \& Archer, 2000) established the widely-accepted Community of Inquiry (CoI) framework. The CoI framework adopted the existing concept of social presence and defined it as "the ability of participants...to project their personal characteristics into the community, thereby presenting themselves to the other participants as "real people"" (Garrison et al., 2000, p. 89). This definition emphasized the actual communication behaviors over the quantity of interactions. While Garrison and his colleagues would show that social presence could be established using only asynchronous text (Rourke, Anderson, Garrison, \& Archer, 2001), researchers have more recently found that social presence can be established more efficiently when students and instructors communicate using asynchronous audio and video (Borup, West, Thomas, \& Graham, 2014; Thomas, West, \& Borup, 2017). Garrison et al. (2000) also explained that social presence impacts students' cognitive presence because it allows for the meaningful and sustained communication that is required to co-construct knowledge of the course material. However, Garrison et al. (2000) stated that neither social nor cognitive presence was likely to reach adequate levels without teaching presence, which they viewed as the "binding element" of the framework (p. 96). More specifically, Anderson, Rourke, Garrison, and Archer (2001) stated that teaching presence is established through instructional design and organization (e.g., setting curriculum, designing methods, establishing time parameters, selecting technology, and establishing netiquette), facilitating online discussions (e.g., identifying areas of agreement, seeking consensus, reinforcing student contributions, setting the climate for learning, prompting participation, and assessing the efficacy of the process), and direct instruction (e.g., presenting content, summarizing discussions, diagnosing misconceptions, providing feedback, and responding to technical concerns). 
While the above frameworks can help to guide K-12 online learning research, their applicability to the K-12 setting is limited due to the unique characteristic of K-12 online learners and environments. As compared to adult learners, K-12 students require higher levels of support (Roblyer et al., 2007). While this additional support can come from the online teacher, it also frequently comes from parents, on-site facilitators, and other adults. As a result, Borup, West, Graham, and Davies (2014) developed the Adolescent Community of Engagement (ACE) framework to better describe the support most likely to increase adolescent online students' affective, behavioral, and cognitive engagement. The primary hypothesis of the ACE framework was that student engagement is positively correlated with teacher, parent, and peer engagements. Because parent and peer engagements are beyond the scope of this research, this section will focus on the concept of teacher engagement, which includes the following:

- Instructing: Using content and pedagogical expertise to support students in their efforts to learn and apply course content. Instructing activities include asking and answering questions, drawing students' attention to course concepts, providing students with resources, summarizing student discussions, tutoring, and providing feedback.

- Organizing and designing: Providing students with an organized online learning environment and helping them to organize their learning schedules.

- Facilitating interaction: Supporting and engaging students in their interactions with the course content and other involved people by

- nurturing caring relationships with students;

- monitoring and motivating students' engagement, progress, and learning; and

- encouraging communication with and between students, parents, and other stakeholders.

The authors of the ACE framework (Borup et al., 2014) encouraged researchers to use a variety of methods such as surveys, interviews, participant reflections, and observations to describe teaching engagement in K-12 online learning environments, claiming that "such research could refine and/or expand the ACE framework and, more importantly, identify the critical components to student success" (p. 23). The ACE framework was first applied to case study research conducted at a successful cyber high school where students took all or most of their courses online and learned primarily at home. Analysis of surveys and interviews with teachers, students, and parents provided a rich description of teacher engagement that largely confirmed the constructs of teacher engagement (Borup, Graham, \& Drysdale, 2014; Borup \& Stevens, 2016b, 2017). However, the ACE framework authors (Borup et al., 2014) also warned that research examining one model of learning should not be generalized to others because "in the several types of existing learning models, each requires different levels of teacher, parent, and peer engagement" (p. 23). For instance, research conducted at a large independent study program found that while online teachers were available to help their students, students most frequently turned to local teachers not affiliated with the online high school for support (Oviatt, Graham, Davies, \& Borup, 2018).

Research has found that while K-12 online teachers can develop strong caring relationships with students, those relationships can take longer to develop and requires active student participation (Velasquez, Graham, \& West, 2013a; Velasquez, Graham, \& Osguthorpe, 2013b). Large enrollment courses can also be an obstacle to providing adequate student support (Hawkins, Barbour, \& Graham, 2011; Hawkins, Graham, \& Barbour, 2012). Furthermore, the types of 
support that online teachers provide are somewhat limited due to their physical distance from their students (Borup, Graham, \& Drysdale, 2014). Online programs are also increasingly requiring local schools to provide their online students with facilitators who can support students in person, at times in a lab setting. Because students receive some face-to-face and online support, this model of learning can be seen as a type of blended learning. Staker (2011) used the term online-lab model to describe environments where online students regularly worked with an on-site facilitator in a lab environment. Specifically, Staker (2011) defined the online-lab model as "programs that rely on an online platform to deliver the entire course but in a brick-and-mortar lab environment. Usually these programs provide online teachers. Paraprofessionals supervise but offer little content expertise" (p. 8). Only recently has the ACE framework been applied to the online-lab model (Borup \& Stimson, 2019). Following their research, Borup and Stimson (2019) recommended that the ACE framework be expanded to include two additional constructs-(1) advising students regarding online course enrollments and (2) orienting students to the online course environment and expectations. In the following section we more fully describe the roles of on-site facilitators.

\section{On-site Facilitators}

On-site facilitators (also commonly called mentors, coaches, or guides) are not content experts but are knowledgeable about how to successfully learn online. On-site facilitators' responsibilities can be summarized as ensuring that "everything is working smoothly and order is maintained" (Hannum, Irvin, Lei, \& Farmer, 2008, p. 213). While on-site facilitators are commonly certified teachers, on-site facilitators' responsibilities do not require content expertise and can be addressed by other school employees such as administrators, office assistants, librarians, and coaches (de la Varre et al., 2011; Hannum et al., 2008; Harms et al., 2006). Following interviews with 58 on-site facilitators in rural K-12 schools, de la Varre et al. (2011) found that the on-site facilitators were commonly certified teachers who had pre-existing relationships with students. Barbour and Mulcahy (2009) also noted that those who are tasked with serving as on-site facilitators are commonly not provided with time or incentives to fulfill their responsibilities. Instead, programs rely on "volunteerism and the good will of overworked teachers" (p. 782).

Harms et al. (2006) were some of the first researchers to list on-site facilitator responsibilities, which included:

- advising students on course enrollments,

- getting to know students on a personal level,

- helping students develop online learning skills,

- fostering communication with and between students, parents, and online teachers, and

- monitoring students' progress and grades.

In one of the largest and earliest studies on the topic, Roblyer et al. (2007) evaluated an online program that used online teachers and on-site facilitators to support students at over $100 \mathrm{~K}-12$ schools. What made this research especially helpful is the scope of their data collection which included student achievement data, teacher and student surveys, and interviews with facilitators, teachers, and students. Their research found that the facilitators played a critical role in student success. However, teachers also found that facilitators needed better training - especially with troubleshooting skills - and that students required more "daily facilitator support and monitoring" (p. 40). 
On-site facilitator responsibilities can also vary depending on the time of semester. Borup and Stimson (2017) interviewed successful on-site facilitators and online teachers and found that at the start of a semester facilitators spent the majority of their time (1) orienting students to the online learning course and accompanying expectations, (2) supplying and troubleshooting technology, and (3) building relationships with students. Later, facilitators spent increased time (1) monitoring and motivating student engagement and (2) facilitating instructional support from the online teacher and local content experts. At the end of the semester, facilitators primarily focused on (1) proctoring exams, (2) using a variety of rewards and punishments to encourage students to finish the course, and (3) recording grades. While teachers attempted to motivate and develop relationships with students, they found their attempts to be limited and were especially dependent on on-site facilitators to develop student relationships and to motivate students to fully engage in the course. In qualitative research that included 40 rural high schools, Kean, de la Varre, Irvin, and Hannum (2008) found that facilitators were especially important "when online instructors were unavailable to students, or in some cases insensitive to their needs" (p. 43). They also found that students' abilities to have a positive online learning experience was dependent on the on-site facilitators' ability to develop relationships with students and their families. Inversely, de la Varre, Irvin, Jordan, Hannum, and Farmer (2014) asked unsuccessful online students and their on-site facilitators why they failed their courses and found that while challenges in understanding the content was in part to blame, more frequently issues surrounding learning online and the lack of motivation was to blame. The researchers concluded that the students would have been more successful if on-site facilitators were more readily available and able to assist and motivate them.

The quality, quantity, and types of facilitation can vary greatly across schools. For instance, some on-site facilitators work with students daily in labs, while others only meet with students on an as-needed basis (Freidhoff, Borup, Stimson, \& DeBruler, 2015). Online students who study daily in a structured lab environment with an on-site facilitator are significantly more likely to pass their courses than are students who have more flexibility in when and where they work (Roblyer et al., 2008). Hannum et al. (2008) conducted a cluster-randomized control trial that also found on-site facilitators were most effective if they received professional development. Specifically, using several discussion board activities, on-site facilitators at rural high schools received extended professional development that encouraged them to share anecdotes from their work and discuss authentic scenarios that were presented using text, images, and audio (Irvin, Hannum, Farmer, de la Varre, \& Keane, 2009; Kean et al., 2008).

While on-site facilitators are not charged with teaching the content, research has repeatedly found that facilitators provide students with some direct instruction. For instance, de la Varre et al. (2011) found that certified teachers who served as on-site facilitators were more likely to engage in content support and instruction than were those facilitators who were not certified teachers. Barbour and Mulcahy (2004) qualitatively examined an online program where on-site facilitators were explicitly told that their responsibilities did not include providing direct instruction or tutoring. However, in practice it was found that on-site facilitators regularly provided students with instructional support, especially when the facilitator had some content expertise. Similarly, O'Dwyer et al. (2007) surveyed 231 online students enrolled in online algebra courses and found that over two-thirds asked their on-site facilitators for math assistance even through their facilitators were not certified to teach math. However, this instructional support was not always welcomed by online teachers who believed that on-site facilitators who also taught content to students could undermine core teachers' ability to fulfill their responsibilities (de la Varre et al., 
2011). While some have argued that facilitators should not engage in instructional content support, Hendrix and Degner (2016) believed it was unlikely that on-site facilitators would stop instructing their students, especially in rural settings where facilitators have developed close relationships with students.

While previous research has provided important insights, it has relied largely on online teacher and on-site facilitator perceptions. As a result, the focus of this research is to hear and understand students' perspectives and experiences regarding ways their online teachers and onsite facilitators supported them throughout their online course. By understanding students' perceptions and experiences, we hope to provide important insights to online teachers and on-site facilitators regarding how their support efforts are being received by students and how they might work to improve their practice. Furthermore, previous research has tended to examine online teachers' efforts and on-site facilitators' efforts separately. While the ACE framework acknowledged that roles outlined in the concept of teacher engagement could be filled by multiple individuals, including an online teacher and on-site facilitator, it did not describe how online teachers and on-site facilitators might specifically share those responsibilities. Harms et al. (2006) explained that, in practice, there is "considerable overlap" between online teachers" and on-site facilitators' responsibilities, and on-site facilitators can at times act as teachers, and online teachers can act as facilitators. By examining students' perspectives of both sources of support simultaneously, we hope to add some clarity to how teacher engagement responsibilities can be shared by online teachers and on-site facilitators.

\section{Methods}

\section{Context}

Research was conducted in three Michigan brick-and-mortar K-12 schools that had 82, 197, and 407 online student enrollments from students who were supplementing their face-to-face course work with online courses offered by Michigan Virtual (MV), a state-run virtual school that enrolled 10,426 students during the 2016-17 academic year. Michigan provided an especially interesting context for this research because Section 21f of Michigan Public Act No. 60 (2013) required local schools to provide on-site facilitators to their students who are enrolled in online courses. However, Section $21 \mathrm{f}$ only stipulated that the on-site facilitator "monitor the pupil's progress in the course" and be "available for assistance to the pupil." Teachers were charged with "determining appropriate instructional methods for each pupil, diagnosing learning needs, assessing pupil learning, prescribing intervention strategies, reporting outcomes, and evaluating the effects of instruction and support strategies" (Michigan Department of Education, 2014, 5-OD-2). Following these directives, on-site facilitators and online teachers have great leeway in how they actually fulfill their responsibilities. MV also provided onsite facilitators and online teachers with guides that offered more information on their responsibilities.

\section{Data Collection}

In a different study conducted during the 2015-16 academic year, 12 schools were identified that had student pass rates of $85 \%$ or higher. Researchers then interviewed the on-site facilitators at those schools to better understand how they perceived their roles and then actually worked to fulfill these responsibilities (see Borup \& Stimson, 2019). Following that research, we sampled three of the 12 schools that had particularly engaged and supported on-site facilitators. 
The three school student bodies ranged between $650-820$ students. Each high school was the only one in its city. Cities ranged in population from 4,500-8,000.

With facilitators' cooperation at the three schools, all parents of enrolled MV students were invited to provide consent for us to survey and conduct focus groups with their students. The survey used in this research was created by adapting a survey created by Oviatt, Graham, Borup, and Davies (2018). The original survey listed types of support identified in the ACE framework. Once students indicated they received a specific type of support, they were asked who had provided them with that support. Oviatt et al. (2018) developed the survey by first identifying each support type outlined in the ACE framework. They then created a statement to represent each of those support types. To ensure that the items accurately represented the framework, the lead author of the ACE framework served as an expert reviewer and suggested changes for clarity. Lastly, an online high school student participated in a think- aloud interview where the student shared his perceptions of what each item meant. However, the instrument was created specifically for an online independent study context and did not address some of the support types that were previously identified following an analysis of teacher and on-site facilitators at MV, especially advising students on course enrollments and orienting them to the online learning environment and expectations. As a result, some items were added to the survey to address those gaps. An MV representative then reviewed the instrument and expressed concerns regarding its length. To address this concern, some items were collapsed into more general items. The length of individual items was also reduced when possible and items were changed to past tense. For instance, the original item "Review the policies of the online school and course with you at the beginning of the course" was changed to "Reviewed the policies and expectations for learning online."

All 70 MV students who completed the survey were also invited to participate in focus groups. The focus group questions were similar to the survey questions. However, the focus group questions encouraged students to share experiences and elaborate on the types of support that they reported receiving on the survey. In addition, the focus groups focused on the value that students placed on the support they received. As a result, both the survey and the focus groups helped to address the first research question and only the focus group allowed us to address the second research question.

Each focus group contained 4 to 9 students and lasted 45 to 60 minutes. Two focus groups were conducted at two of the schools, and four focus groups were conducted at the third, for a total of eight focus groups with 51 student participants: one freshman, seven sophomores, 11 juniors, and 32 seniors. Of the 32 seniors, 18 had taken online courses during previous semesters. For privacy purposes, we have renamed the schools and student participants. All data collection and analysis procedures were approved by the lead author's university institutional review board.

\section{Data Analysis}

The first research question was addressed by identifying the types of support indicators that students reported receiving in their survey and focus group responses. Student survey responses were analyzed using descriptive statistics. The value that they placed on the support that they received - the focus of the second research question-was determined in students' focus group responses. Student focus group recordings were transcribed and sent to student participants to check for accuracy. Following what Glaser (1965) called the "basic, defining rule for the constant comparative method" (p. 439), one of the researchers coded focus group comments into as many different categories as possible while comparing them to all previously coded comments. 
Similar categories were then grouped together. The groupings were guided by, but not limited to, the elements identified in the ACE framework. Groupings were also reviewed by the entire research team three times during the analysis - once for each school's focus groups. In the meetings, the group commonly highlighted specific statements that they believed were different from the other statements similarly coded. The group also highlighted subcategories to discuss if they would fit better under another coding category or become its own category. All disagreements were discussed until resolved.

\section{Results}

For the survey, 70 students reported the support indicators they had received and then indicated whether the source of that support was their online teacher and/or on-site facilitator (see Table 1). The two most commonly reported support indicators focused on monitoring students' progress and checking in with students to ensure they were working hard to progress through the course. On-site facilitators appeared to be the primary source for both activities. In fact, overall, on-site facilitators were reported as the support source over $30 \%$ more times than were online teachers and more frequently than online teachers on 10 of the 16 indicators. While online teachers were reported most frequently as the support source on six support indicators, the differences were most prominent on three: providing feedback on assignments, helping students communicate with peers online, and helping students create learning schedules. Overall, relatively few students reported receiving help on deciding which online course(s) to take. Similarly, two of the four least reported support indicators focused on helping students to communicate and collaborate with their peers.

Table 1.

Number of Survey Participants Perceiving Support Indicators and Source of Support

\begin{tabular}{lccc}
\hline Support Indicators & & \multicolumn{2}{c}{ Source } \\
\cline { 2 - 4 } & $\begin{array}{c}\# \text { of } \\
\text { Participants }\end{array}$ & $\begin{array}{c}\# \text { of } \\
\text { Facilitators }\end{array}$ & $\begin{array}{c}\# \text { of } \\
\text { Teachers }\end{array}$ \\
\hline $\begin{array}{l}\text { Checked in with you to make sure you were working hard } \\
\text { to complete assignments. }\end{array}$ & 61 & 51 & 22 \\
Checked your grades/progress regularly. & 59 & 49 & 27 \\
Gave you course materials. & 56 & 49 & 19 \\
$\begin{array}{l}\text { Explained things to you when you had questions. } \\
\text { Showed you how to use Blackboard. }\end{array}$ & 55 & 37 & 41 \\
Reviewed the policies and expectations for learning online. & 45 & 39 & 28 \\
$\begin{array}{l}\text { Helped you if you were having computer or internet } \\
\text { problems. }\end{array}$ & 45 & 31 & 35 \\
Motivated you to complete assignments. & & 36 & 12 \\
\hline
\end{tabular}




\begin{tabular}{lccc}
\hline Support Indicators & & \multicolumn{2}{c}{ Source } \\
\cline { 2 - 4 } & $\begin{array}{c}\text { \# of } \\
\text { Participants }\end{array}$ & $\begin{array}{c}\# \text { of } \\
\text { Facilitators }\end{array}$ & $\begin{array}{c}\# \text { Tef } \\
\text { Teachers }\end{array}$ \\
\cline { 2 - 4 } $\begin{array}{l}\text { Provided you with feedback on your assignments (before or } \\
\text { after they were submitted). }\end{array}$ & 44 & 11 & 40 \\
Made sure you had a place to study. & 43 & 37 & 9 \\
$\begin{array}{l}\text { Helped you gain the skills you needed to successfully learn } \\
\text { online. }\end{array}$ & 41 & 32 & 29 \\
Helped you set goals for completing assignments. & 40 & 25 & 29 \\
Helped you learn how to communicate with others online. & 32 & 10 & 30 \\
Helped you decide which online course(s) to enroll in. & 31 & 30 & 7 \\
Helped you create a study schedule. & 24 & 10 & 18 \\
Helped you work with other students on assignments. & 23 & 15 & 13 \\
\hline
\end{tabular}

Analysis of focus group transcripts identified the following support categories: (1) advising students regarding course enrollments, (2) orienting students to the online course platform and expectations, (3) facilitating communication, (4) nurturing caring relationships, (5) monitoring student progress and learning, (6) motivating students to more fully engage in learning activities, and (6) teaching the course material (see Table 2). Students' comments regarding the support they received from their on-site facilitators was almost entirely positive. This is likely the result of our purposeful sampling of facilitators who were particularly engaged in students' learning. In contrast, student comments regarding the support they received from their online teachers were more divided and tended to be more negative in some categories.

Table 2.

Number of Focus Groups Containing Positive and Negative Comments on Support Categories

\begin{tabular}{lccccc}
\hline Support Category & \multicolumn{2}{c}{ On-site Facilitator } & & \multicolumn{2}{c}{ Online Teacher } \\
\cline { 2 - 3 } \cline { 5 - 6 } & $\begin{array}{c}\text { Positive } \\
(\mathrm{n}=\text { Groups })\end{array}$ & $\begin{array}{c}\text { Negative } \\
(\mathrm{n}=\text { Groups })\end{array}$ & & $\begin{array}{c}\text { Positive } \\
(\mathrm{n}=\text { Groups })\end{array}$ & $\begin{array}{c}\text { Negative } \\
(\mathrm{n}=\text { Groups })\end{array}$ \\
\hline Advising & 4 & 1 & & 0 & 0 \\
Orienting & 8 & 2 & & 7 & 7 \\
Facilitating Com. & 8 & 1 & & 8 & 8 \\
Nurturing & 8 & 1 & & 8 & 8 \\
Monitoring & 8 & 4 & & 7 & 8 \\
Motivating & 8 & 3 & & 4 & 4 \\
Instructing & 2 & 0 & & 8 & 8 \\
\hline
\end{tabular}




\section{Advising}

Even before courses began, those who were new to online learning tended to seek guidance from a knowledgeable adult regarding whether enrolling in an online course was in their best interest. However, some students did not perceive a need to be advised, and students in only four focus groups stated that they turned to their on-site facilitator for advising support. Sharron summarized her thought process as, "There's an online class. Let's do it." Courtney added that she "decided all by [her]self" and was "jumping at the opportunity."

Students in two of the schools commented that their on-site facilitators provided them with high levels of advising support. In fact, one student, Wyatt, commented that his on-site facilitator was "almost...one of the [school] counselors sometimes, which is really nice." These on-site facilitators seemed to be particularly helpful because they were familiar with students' goals and interests. Jason summarized, "He did help me figure it out because he kind of knew what I was already interested in and then just recommended different things that I could try." Sophia added that it was especially helpful when the on-site facilitator "would have another student who took the class already to come and have a conversation with [her] about what to expect." Another student was left to "sort of just guess on what...to take" and would have preferred more support.

\section{Orienting}

Students required access to the required learning materials and needed to become oriented to the online learning environment and course expectations. During the semester prior to conducting this research, MVU had placed a "Unit 0" in each of the students' online courses that helped students become familiar with course expectations and the learning management system (LMS). Sara described the unit as "a slideshow of exactly what to do, how to message [the online teacher], how to access lessons - everything." Sage added that Unit 0 also had to pass an assessment before they could "actually move on to [their] class content." The unit also contained course expectations regarding student behavior, effort, and workload. Bob added, "As far as expectations and requirements go, like plagiarism, cheating, they make sure they hammer that point home, that's not allowed." While Unit 0 appeared to be helpful, Sage found it to be a "little tedious once you've taken multiple classes and you have to do it over and over again."

Students found that Unit 0 reduced their dependency on their online teacher and on-site facilitator. Kacee stated that before Unit 0, "you kind of had to learn it yourself, or [the on-site facilitator] would explain it." While Unit 0 was helpful, students still needed orienting support from their online teacher and on-site facilitator. For instance, Stephanie's on-site facilitator actually "went through some of Unit 0" with her. Online teachers also created course announcements with more course-specific information and video tutorials. While some students found the announcements and video tutorials to be "kind of cool," Cole admitted that he "never read" them.

Students explained that they could email their teacher for orienting support, but the online teacher "wasn't by our side telling us." For that reason, students tended to turn to their on-site facilitator to get help "right away." On-site facilitators also provided students with whole-group direct instruction that showed them "step-by-step how to get online and how to sign in." Brooke shared, "The first classes, he always explains how [the LMS] works. He goes through everything and shows you the steps to use it." Students also explained that their on-site facilitator would set expectations: "being on time, and coming to class, and...maybe doing [work] at home." On-site 
facilitators also stressed the need to follow the course-provided pacing guide "because otherwise you're going to regret it later in the semester."

On-site facilitators proved to be less effective at troubleshooting technological issues that commonly occurred at the start of the semester. For instance, Sage explained that it "took about a week probably to figure out... [how] to get the cameras to hook up to our computers." However, students tended to turn to their facilitator regardless because it was better "than trying to message my instructor and having to wait a whole day to get a response back." As a result, students found that "a tech issue can shut you down for the entire day." Adam advocated for more "on-the-spot tech help."

\section{Facilitating Communication}

Students expressed a wide range of emotions and experiences regarding their interactions with the online teacher. Some students were comfortable contacting their online teachers because "they're not physically there so it can't be socially awkward." Some students, such as Kami, also found that teachers adequately responded to their needs because "you can always message the instructor and get what you need." Online teachers typically "got back with you within 24 hours." Sophia did not seem to mind having to wait: "The great thing about online is if you're having problems with an assignment, you can email your teacher and actually go on to the next assignment depending on what course you take."

While some students were highly positive when describing their communication with the online teacher, over two-thirds of students' comments regarding their communication with their online teachers were negative. This was partly because some students struggled communicating via email. Holly explained, "I don't really like communicating email-wise, and that's pretty much all you do. It's something to get used to." David added that "trying to ask a certain question can get a little tedious." However, most of students' frustration and dissatisfaction stemmed from having to wait too long for a response. Jessica explained, "It's kind of frustrating because I also can't skip ahead because it might be something essential that I need to know." Furthermore, four students shared experiences where their online teacher did not adhere to the 24-hour response time guideline and experienced "three to four days where they didn't respond." Madalyn added that online teachers' slow response time made her feel like she was "just bugging them," so she did not "ask a lot of questions like [she] should." Overall, students had to learn to "be patient and wait" when communicating with the online teacher.

While students had mixed perceptions and experiences communicating with their online teachers, students were almost entirely positive regarding communication with their on-site facilitators. Unlike emailing the online teacher, which could be time-consuming and "tedious," students found interactions with the on-site facilitator to be immediate, comfortable, and natural. Landon shared, "You could just walk in their class, ask them a question, and they'll have an answer for you." Furthermore, students believed their on-site facilitators enjoyed communicating with them. Angela explained, "He is so happy to help all the time... He loves helping in any way he can... I will gladly go to him for help." The only critique was when students were not learning in a lab setting, making it difficult to communicate with the on-site facilitator because they would "have to go and look around the school for him." Stella had a unique perspective because she was enrolled in two courses - one required her to work in a lab, and the other allowed her to work in the library when she was "ahead of pace." She shared, "I go into the library but then it's hard to 
find [the on-site facilitator] whenever I need to; whereas in the lab, he sits right in front of me and I can ask him anything."

Not only did on-site facilitators effectively communicate with students, they also helped facilitate student-teacher communications. In describing his on-site facilitator, Wyatt shared, "He's very willing to talk with your teacher on your behalf...and so a lot of times he's communicating with our teacher just as much as we are."

\section{Nurturing Caring Relationships}

Despite the obstacles to communicating with their online teacher, some students in all eight focus groups indicated they were able to form close, positive relationships with their online teacher. Of the focus group participants, perhaps Beth was able to form the closest relationship with an online teacher:

I ask my teacher a lot of questions. I email my teacher all the time, trying to schedule stuff and then when I have problems with an assignment, or when I submit an assignment she'll comment on it and be like, "You did really good at this." She asks a lot of questions too, so she'll be like, "Oh, how did you do that?" So we'll email back and forth just about personal stuff, just getting to know each other, just talking about the assignments. That's nice. It's really good to communicate.

Online teachers' self-disclosure seemed to help students see their teacher as "a real person." For example, Stephanie's Spanish teacher would say things such as, "Hey, I can't be teaching today because my daughter's sick," which made Stephanie think, "Oh, he is a real person. He has kids." Kacee added, "My teachers use bitmojis in their announcement boards, so I'm like, 'Oh, they're friendly." She also enjoyed it when her teacher facilitated social communication by asking students to participate in "a little discussion board where we told each other what we dressed up as for Halloween and what we're doing for Thanksgiving and Christmas to keep it more social." Kacee believed that the social interactions actually had academic implications "because it makes it a lot easier if you need help, you can just message one of the other students in the course even if they don't go to your school."

However, nearly two thirds of students' comments indicated that their teacher interactions lacked meaningful social interaction. Stella believed that his online teachers "don't interact with you unless they need to." Gina added, "My online teacher doesn't really communicate with me unless I get something wrong." The lack of social interaction made it difficult for students to fully trust their online teacher. Rick summarized, "So you can trust them to be fair with grading the work, but not really in relation to other things." Sandy added that she was less likely to follow the direction of the online teacher because "it's just a stranger telling me that." Some students went as far as saying, "It feels like you're talking to a robot."

While students generally did not feel like they were able to develop positive relationships with online teachers, it is also important to note that some students did not feel a need to. Harper stated that "there isn't much of a need [to build a relationship] beyond grading what you submit." In fact, some students believed that it "might be weird." Sandy shared that she had a teacher who "kept asking us questions about our lives" and would share family photos and give "updates about her life and in the discussion boards sometimes use real life examples." Sandy found attempts at these types of social communication "kind of weird because you've never met them." 
Students in one focus group argued that it was more important to form close relationships with their on-site facilitator than with the online teacher because they "see [their facilitator] at least four out of five days a week" whereas they could "go the entire year without having to email or talk to [their online teacher]." Furthermore, they acknowledged that their relationships with onsite facilitators were more important because they saw them throughout their high school years, "whereas every online class has a different teacher." In reference to her relationship with the online teacher, Sandy asked, "What's the point of building the relationship? They're not really going to get to know you that well and you're not going to have them possibly ever again."

Students found they were able to form "way better" relationships with their on-site facilitator because they regularly communicated face-to-face. Roger shared, "[My on-site facilitator] walks around all day talking to all different kids about how we're doing even outside of our class, so he tries to get to know everyone to build trust with them." Similarly, Sage stated that her communication with her facilitator was not "superficial...he'll actually ask, 'How is your day going?' and he'll actually mean it." Furthermore, Levi found that, "Everyone likes [the facilitator] because he just connects to you on a personal level and he doesn't care who you are, how popular you are, whatever." Cynthia added that on-site facilitators could recognize non-verbal cues and know when she was "having an off day at school and they'll come talk to me but with online [teachers] they can't see and so they don't know that." Over time students explained that they formed close, caring relationships due to facilitators' friendly and positive demeanor. For instance, students at one school stated that their on-site facilitator was "very, very personal," "super friendly," and "one of the nicest faces here." Another student went as far to say, "I definitely feel like he's my friend but also my [facilitator]."

\section{Monitoring and Motivating}

Some students believed that teachers regularly monitored their progress in the course. John explained, "I feel like they monitor your grades as much as a normal teacher would--they have to. A major part of their job is just grading the work." Madalyn recalled that her online teacher would send her "progress reports every couple of weeks" and would email her when her "grades are getting low or anything." In contrast to Madalyn's experience, some students did not believe that their online teacher monitored their progress because teachers did not contact or try to motivate them when they had fallen behind. For instance, Raymond was "getting a fairly good grade" and did not receive personalized emails about his progress. Similarly, Rick admitted that "he just kind of forgot that [he] had the class" and did not hear from his teacher until the middle of the semester. The experience made him ask, "Does [my online teacher] even know that I'm not doing it at that moment?" Similarly, Sharron recalled turning in work after being four weeks behind: "The instructor didn't care [that I had fallen behind], they just graded everything and were like, 'good work' but nothing was mentioned of it, that I even fell that far behind."

When one student stated that online teachers monitored students' progress more than faceto-face teachers, Sara countered, "I feel like they monitor our grades maybe more, but I feel like they care less about what the grade is." Similarly, Sandy stated, "I don't really get a lot of motivation from my actual teacher." Even when online teachers recognized students' progress and sent students motivational messages, their efforts appeared to have little impact on students. Rick found that encouraging statements such as "You're doing good," felt "more like a set response than a motivator." Madalyn added that teachers could be more motivational if they "have better communication skills." 
In contrast, students believed their on-site facilitator closely monitored their progress and effectively motivated them to more fully engage in learning activities. Students shared that their on-site facilitator also met with them regularly to discuss their progress. Beth stated, "Every Friday, [my facilitator]... comes by you and says, "Hey, you're here. You have this percent so you have this and this and this due to get [caught] up." Cole elaborated that these meetings did not need to be long, "He'll just call you up for a minute, 'So how's it going? You're working on your course.' He always checks in." Kacee added, "Even though you think it's irritating, [my facilitator] will pull you out of other classes to see how you're doing." Adam, who admitted that he was "not responsible enough to check [his progress] for [him]self," appreciated the "helpful checkups" with his on-site facilitator because they helped to "make sure that [he was] up to date."

Students also found that facilitators effectively motivated them to more fully engage in learning activities. In part, this motivation was a result of their relationship with the on-site facilitator. Bob shared, "Since he is so invested in our lives...you respect him in that way. You also want to do your work, just naturally want to do it." Facilitators also used a combination of rewards and punishments to engage students. Students explained that their facilitator would "get on your case" when they were behind, but also "gives you incentives." For instance, Angela shared that if you are caught up in the course "you can leave, you have freedom...but if you're behind you have to stay back and catch up." At times facilitators also contacted parents to motivate students because "parents don't really check on there to see [their students' grades]." Kacee said that she was unaware that her facilitator had contacted her parent until she went home and her mom said, "Go do your online [course.]... I know you're behind.... Do it at the kitchen table." While a few "really self-motivated" students claimed that their facilitator's efforts were unnecessary, most students valued their motivational efforts.

On-site facilitators seemed to be especially effective at monitoring and motivating students because the majority of students were required to attend a daily lab time. Several focus group participants reported that they believed lab time was important and often integral to student success. Cynthia explained:

I think it's important for you to have a set amount of time to work on your class. If you're not a self-motivated person, then [lab time] is set right there for you. Maybe it's not perfect for everybody. For me it's really good. I might not have time at home to do it, so then I have time at school.

Stephanie believed

The lab is good because you're under the eyes of the facilitator and your fellow classmates.

You just kind of feel the drive to be like, "Oh, I need to be working on it." It helps you stay focused on what you need to be getting done.

Raymond reiterated that "sociologically speaking, seeing other people doing their work makes you want to. It's just that peer to peer thing...you naturally follow along."

Attending a lab with other students could also prove distracting, and on on-site facilitators were required to manage students' behavior to ensure they remained on-task. Katie explained, "If you're sitting in there playing on your phone, then he'll come up and approach you." According to Sage, "Having a facilitator or a teacher around, ...it's quieter [and] eliminates a lot of distractions." Charles said, "We usually keep quiet and have everybody learn their own stuff," but when there were distractions, the "facilitator [would] tell them to be quiet and focus." 


\section{Instructing}

While working on assignments, students commonly required content support. Bob explained, "[Online teachers] definitely offer their help. It's definitely there if you need it." Cynthia was enrolled in a sign language course and found that the teacher did "a good job of explaining things" and "would change her directions to make them more clear for [her students]." However, few students actually shared times when they received content-related support prior to submitting an assignment. Raymond, who was enrolled in a pre-calculus course, found it difficult to ask the online teacher via email specific questions about "how to solve x equation," so his "first course of action would either be to look up a YouTube video on how to solve the equation, maybe ask a peer,...or go ask one of the math teachers down the hallway." Lisa also recalled that a friend enrolled in a language course had "to look up different apps to learn the language," because "the guide that [the online teacher] gave them does not really help." At the time Lisa remembered thinking to herself, "Um, I'm pretty sure the instructor is supposed to do that [for you]."

The majority of teachers' instructional support appeared to have come in the form of feedback. Nolan explained that the feedback he received was especially helpful because it helped him "know what to work on for [his] next assignment." Similarly, Alexis found that when she submitted papers, the online teacher gave her "really specific instructions on how to do better and how to include information in a different way." Rick added that the critical feedback he received was delivered in a "really positive" manner, "It's not, 'You did this wrong, fix it immediately.' It's more of, 'Here's how you did it wrong. I can see what you were going for and how that works, but it works better this way." Some teachers went as far as providing students with feedback via audio or video recordings. Brooke shared, "For my sign language course she leaves video comments and tells me what to fix, and that's really helpful so I know how to do it better."

While most of the students' comments were positive, they also found that teachers could vary greatly in the quality and quantity of their feedback. Angela stated,

I feel like each class is different because with one of my classes my teacher gives me like, "You did good on this, but you can work on this for your next assignment," but then my other class they don't give you anything, so you don't know what to improve upon.

Brooke also expressed frustration because she "didn't get anything back [on her] writing assignments so [she] didn't know if they were good or bad." Other students found that they received high or perfect scores and generic "Good job!" comments even when they put very little effort into the assignment, making them question how closely teachers actually read their work. For instance, Alexis' teacher told her "Great job!" and gave her "100\%" on papers she believed she "did terrible on." Holly summarized, "There's definitely big extremes between the feedback."

While they were not content experts, students in two focus groups stated that their on-site facilitators occasionally assisted students on projects. For instance, Madalyn's on-site facilitator would review her work in a finance course to "make sure [she would] have the answers right" before she turned them in. Beth described witnessing her peer who "struggles with math all the time" receive regular support from the on-site facilitator, which resulted in her "getting [a] 100\%." Angela said, "I will email my instructor...it just takes days," so she seeks help from her on-site facilitator as well because "he usually helps me until we figure out a solution." 


\section{Discussion}

Graham, Henrie, and Gibbons (2014) stated, "Well-established scholarly domains have common terminology and widely accepted models and theories that guide inquiry and practice, while researchers in less mature domains struggle to define terms and establish relevant models" (p. 13). Widely accepted frameworks have been established in higher education and initial work has begun to establish frameworks in K-12 online learning. However, limited efforts have been made to develop frameworks and theory for blended learning environments in either higher education or K-12 environments (Graham et al., 2014). Specifically, in K-12, researchers have tended to focus mostly on ways that blended learning is structured and less on the types of learning and teaching strategies that occur in those structures (see Staker, 2011). While the online-lab model is similar to fully-online courses, the addition of face-to-face support results in important differences that limit the utility of online learning frameworks. For instance, the Theory of Transactional Distance's concepts of structure and autonomy tends to focus on students' ability to make decisions regarding "what to learn, how to learn, and how much to learn" (Moore, 2007, p. 90) - what is commonly referred to as the learning path in blended learning literature (Staker, 2011). Blended learning also takes a broader view of autonomy that includes students' learning time, place, and pace (Staker, 2011).

There was little evidence that students in our research had autonomy in their learning path and the learning activities and sequence appeared to be fairly set. In fact, our previous research at MV found that online teachers were not allowed to modify the courses even if they recognized that they did not meet individual students' needs (Borup \& Stimson, 2019). The local schools included in this research also somewhat restricted students' ability to exercise autonomy over their learning time and place by requiring them to attend a daily lab. Furthermore, facilitators attempted to exert some control over students' learning pace by closely monitoring their progress and intervening when students lagged behind the pacing guide. Moore (1980) stated that "a learner cannot learn effectively if the educational transaction demands more autonomy than he is able to exercise" ( $p$. 29). While Moore was largely speaking of autonomy over their learning path, the same could be applied to students' ability to exercise autonomy over their learning place, time, and pace. Moore also hypothesized an inverse relationship between structure and dialogue. This holds true when focusing on students' learning path. However, we found that student-facilitator dialogue likely increased as a result of adding structure to students' learning time, place, and pace. As a result, those who apply the Theory of Transactional Distance to blended learning environments should take a broader, more nuanced view of structure, dialogue, and autonomy than what was originally outlined in the framework.

For the first research question, the ACE framework proved helpful in identifying the types of support indicators that students perceived receiving. This research supports the addition of the constructs advising and orienting to the ACE framework. Merriam (1998) explained that the primary purpose of qualitative research is not to "test concepts, hypotheses, and theories" (p. 45). Rather, as Stake (2010) stated, qualitative research is best at understanding "how things work" (p. 16). However, just because a type of support is occurring does not mean that it should be included in a framework. Whetten (1989) explained that researchers may feel a tension between developing a comprehensive framework and one that is more parsimonious. Ferdig, Cavanaugh, DiPetro, Black, and Dawson (2009) also stressed that K-12 online learning researchers should attempt to highlight best practices - not all practices - and that a complete list would actually prove too distracting. In fact, Mishra and Koehler (2006) wrote that one of the primary purposes of a 
framework is to help researchers focus on what is most important and to ignore others. To this point, Whetten (1989) explained that a framework is complete not when it includes all factors but when it contains the right factors. While adding the constructs of advising and orienting increases the complexity of the ACE framework, they appear important enough to warrant their addition.

Orienting students to the online environment could be viewed as a type of instructing, however, it is distinct enough to warrant being its own construct for two reasons. First, the construct of instructing focuses largely on learning the course content and the construct of orienting focuses largely on learning the course platforms, procedures, and expectations. In other words, orienting is focused on helping students "learning how to learn online" whereas instructing focuses on helping students "to learn a subject online" (Lowes \& Lin, 2015, p. 18). Second, by its nature, orienting occurs at the start of the course while instructing occurs once students have begun the course assignments. While it was not originally included in the ACE framework, orienting should not be overlooked by researchers because students' inability to effectively use the platform used to deliver the online course can prove to be a major obstacle to effectively interacting with the course materials, peers, and instructor (Hillman et al., 1994).

Although advising students regarding online enrollments occurs before the start of the course, quality advising can help students to avoid or prepare for challenges they will face in online courses. While advising can include encouraging or discouraging students to enroll in online courses based on their ability, Rose et al. (2015) warned that this type of advising could result in unintentional biases. Instead, Rose et al. recommended that advising should focus more on identifying the types of support that students require. For instance, one type of support that can be offered to students is the opportunity to learn in a lab setting in the presence of an on-site facilitator. In this research, being physically present with students on a regular basis seemed to help on-site facilitators to fulfil their other responsibilities. This may help to explain why research has found that students are more likely to be successful when they learn in a lab setting (Roblyer et al., 2008). The schools included in this research required the large majority of their students to attend a daily lab. Other schools may take a more personalized approach and only require lab attendance when students lack the skills to successfully exercise autonomy over their learning time and place. Schools may choose to require students to attend a lab environment when they are new to online learning but then provide them with more flexibility once they have demonstrated their ability to successfully learn online. Inversely students could be required to begin attending a lab when their performance is inadequate. This more personalized approach could have two benefits. First, it may be a better use of the available resources by focusing on those students who need it most. Second, it may allow students to develop the self-regulation skills they would need when exercising control over their learning place and time.

Not all of the support responsibilities were equally shared across on-site facilitators and teachers. In part, teachers assumed certain responsibilities due to their content and pedagogical expertise whereas on-site facilitators assumed certain responsibilities due to their physical proximity to students. This type of support model works best when online teachers and on-site facilitators coordinate their efforts and clearly understand the scope of their responsibilities (de la Varre et al., 2011). Specifically, de la Varre et al. (2011) recommended that there be an "in-depth instructor-facilitator conversation at the outset of the course" (para. 26). However, in practice it is likely impractical for online teachers to have in-depth conversations with all of their students' facilitators or for an on-site facilitator who works with a large number of students to have in-depth conversations with all of their students' instructors. A more pragmatic and scalable approach 
would be for the course provider to provide online teachers and on-site facilitators with clear expectations for what they should and should not do. For instance, MV provides online teachers and on-site facilitators with detailed guides pertaining to their responsibilities. However, guides are unlikely to provide online teachers or on-site facilitators with the support required to develop the skills needed to effectively fulfill their responsibilities. Practitioners and researchers should collaborate to identify effective approaches to professional development (Dawson \& Dana, 2018). Researchers have already found that students who work with facilitators who have completed extended, scenario-based professional development tended to be more successful than students who worked with facilitators who received no professional development (Hannum et al., 2008). Considering their shared responsibilities, we also recommend that programs explore strategies that allow online teachers and on-site facilitators to participate in professional development jointly so that they have opportunities to communicate one with another and better understand each other's challenges, concerns, and needs.

When addressing the second research question, we found that students did not value their online teachers' and on-site facilitators' support efforts equally across all support indicators. For instance, students valued building relationships with their on-site facilitator more than with their online teacher. Research findings examining student-teacher relationships have been mixed. Similar to this research, Hawkins, Barbour, and Graham (2011) examined student-teacher relationships at a state-run virtual school where teachers reported little social interaction with students. Hawkins et al. (2011) found that teachers believed social interactions would be a "waste of students' time" (para. 42) especially in light of their high student loads. Larkin, Brantley-Dias, and Lokey-Vega (2015) conducted a survey to measure 108 online teachers' satisfaction on five aspects of their job. Teachers ranked their interactions with students the lowest while also having the highest standard deviation, indicating that teachers are more divided on their satisfaction with their student communication than they are with other aspects of their job. In a previous study, online teachers at MV shared several strategies they regularly employed to develop relationships with students. Ultimately, they found that their ability to generally develop relationships with students to be limited, and several found teaching online to be a "solitary business" (Borup \& Stimson, 2019, p. 37). Similarly, Hawkins, Graham, and Barbour (2012) found that a lack of meaningful student-teacher relationships left teachers feeling isolated and disconnected. Inversely, research has found that developing student-teacher relationships improved teachers' job satisfaction at a full-time online high school (Borup \& Stevens, 2016a; Drysdale, Graham, \& Borup, 2016). Furthermore, Lin, Zhang, and Zheng's (2017) analysis of 466 online students' survey responses at a virtual high school found that learner-instructor interactions had a positive relationship with student satisfaction. While not generally the case with the students who participated in our research, previous research at full-time online high schools has found that online teachers were successful in forming close relationships with students through regular, sustained online communication. In fact, teachers and students have reported that these relationships can actually feel closer than the relationships formed in face-to-face learning environments (Velasquez et al., 2013a; Velasquez et al., 2013b).

While some students found their online teachers to be impersonal, they still valued the support they were able to provide. One student explained, "[Online teachers] are robots that help me." The teacher support that was the most valued was feedback on assignments. However, not all feedback was helpful. At times students viewed simple, generic feedback comments on larger projects as an indicator that the teacher had not actually reviewed their project. This was especially true when they put little effort on a project and still received "100\%" and a "Great job!" In contrast, 
some students reported receiving detailed, helpful feedback via audio or video recordings, a practice that has been researched in higher education (Borup, West, \& Thomas, 2015; West, Jay, Armstrong, \& Borup, 2017) but has yet to be examined in K-12 online learning environments. Feedback has been shown to be a critical component in students' learning (Hattie, 2009). However, as supported in this research, Hattie found that "some types of feedback are more powerful than others" (p. 174). Murphy and Rodriguez-Manzanares (2009) highlighted a connection between feedback and motivation for K-12 online students, "Detailed, quality, frequent and prompt feedback are the number one motivator" (p. 9). The opposite also appeared true in our research, where students interpreted poor feedback as a sign that the teacher did not care about them or their learning. Despite its importance, little is actually known regarding teacher feedback practices. Eraut (2006) summarized that "we need more feedback on feedback" (p. 118). This is especially true in K-12 online settings and researchers should use a variety of methods to address this gap. For instance, researchers can conduct interviews with students and teachers as well as analyze actual feedback comments to determine their utility and timeliness. Programs should also provide professional development focused on providing effective feedback.

Students also found that they were unable to receive tutoring or technological support from their online teacher in the moment they needed it. Furthermore, they found it difficult to ask some types of questions via email. As a result, students commonly turned to their on-site facilitator, peers, teachers in their building, or online videos for assistance. However, students still wished they had more "on-the-spot" support from teachers. For subjects such as math, where students must master specific skills before progressing to more advanced skills, online programs may improve students' learning experience by providing them with content experts who could give just-in-time instruction. The need for more immediate instruction helps explain why on-site facilitators in previous research frequently provided students with content support (Barbour \& Hill, 2011; de la Varre et al., 2011; Taylor et al., 2016). However, some online teachers can become frustrated when on-site facilitators provide content support, especially when they are not knowledgeable enough to provide accurate information (de la Varre et al., 2011). It is unrealistic to expect online teachers to always be available to students, especially in online programs that rely heavily on part-time teachers who teach face-to-face full-time during the day. As a result, supplemental online programs and researchers may explore practical strategies for providing students with more immediate content-related support. One potential solution in subjects such as math is to have on-call tutors for students to contact when questions arise similar to tech support call centers.

Students also found that on-site facilitators were especially helpful when they closely monitored students' progress and motivated them to more fully engage in learning activities. Facilitators were especially proactive at personally meeting with students to discuss their progress and at times even pulling them out of another class to do so. In contrast, students believed their online teachers regularly checked their progress but tended not to reach out to them or show any concern when they became inactive in the course. This left some students feeling like their online teacher was not invested in their learning and did not care if they were successful or not. One student shared, "I feel like they monitor our grades maybe more, but I feel like they care less about what the grade is." Student emotions and motivation are strong predictors of K-12 online student success (Kim, Park, \& Cozart, 2013). In fact, Roblyer et al. (2007) argued that student success in online courses has more to do with motivation than with their actual ability to understand the content. As a result, "facilitators that are directly working with students day by day are key to the success of the program" (Roblyer et al., 2007, p. 11). More research is needed that examines 
students' affective engagement and the types of interactions that best form caring relationships with students.

\section{Conclusion}

Online courses tend to have higher attrition rates than face-to-face counterparts, causing some to call for more expensive student support systems (de la Varre et al., 2014; Freidhoff, 2018; Taylor et al. 2016). While learning the actual course content can prove challenging, more frequently it appears that the flexible nature of online learning is most daunting for adolescents who tend to lack self-regulation abilities (Cavanaugh, 2007; Moore, 1993, 2007; Rice, 2006; Weil et al., 2013). Moore (1980) warned that "a learner cannot learn effectively if the educational transaction demands more autonomy than he is able to exercise" (p. 29). Roblyer et al. (2007) explained, "Students' ability to handle distance education courses appears to depend more on motivation, self-direction, or the ability to take responsibility for individual learning" (p. 11). As a result, many students are failing online courses, not because they cannot learn the course content but because they cannot efficiently "learn now to learn online" (Lowes \& Lin, 2015, p. 18). Many programs now require that students' local brick-and-mortar schools provide them with on-site facilitators. Little is known about how students perceive the support they receive from their online teachers and on-site facilitators. In this research we found that students received a high level of support from both online teachers and on-site facilitators, with most of the support coming from the latter. This is in part because students felt somewhat uncomfortable communicating with teachers via email and became frustrated when having to wait a day - and at times much longerfor a response. Students also appeared to be more comfortable communicating with their on-site facilitators face-to-face and found them to be more accessible. One student explained that it was "easier to ask someone in person." Students explained that they were comfortable communicating with their on-site facilitators because they were able to develop caring relationships with them through regular, sustained communication that often included social and personal topics. In contrast, students' communication with their online teacher tended to focus mostly on course content. In fact, when teachers did share personal information or tried to get to know students on a personal level, their efforts were appreciated by some while others thought that it was "kind of weird because you've never met them." Students also tended to see less value in forming relationships with their online teacher because those relationships ended with the course, whereas their relationships with the facilitator would extend further-possibly through all of their high school years. However, students still lamented that their online instructors felt more like "robots" than humans. Murphy and Rodriguez-Manzanares (2009) also recognized this issue and explained that teachers should work to establish a "personal connection, so students understand that there is a person behind the computer and not a robot" (p. 8).

It is important to note that the three local brick-and-mortar schools sampled in this research were purposefully selected based on their high student pass rates and their impressive levels of onsite facilitator engagement. Research has found that on-site facilitator engagement can vary greatly across schools; thus, the findings from this research cannot be generalized to other settings. Onsite facilitators in this research were highly engaged and successful at developing close, caring relationships with students, which likely reduced students' perceived need to also develop similar relationships with their teachers. In cases when students have not developed close relationship with on-site facilitators, they may feel more of a desire to develop a relationships with the online teacher. As a result, additional research is needed that examines student-teacher relationships- 
especially from the student perspective-in various settings including supplemental online programs where students are not provided an on-site facilitator or where students' facilitators are not as highly engaged in their learning. It is also possible that online teachers prioritized their efforts to develop relationships with students in schools with less engaged facilitators. More research examining teachers' perceptions and strategies would provide additional insights. Future research should also use different methods such as direct observations and one-on-one interviews. While difficult, these type of research efforts could provide important insights into how students receive and perceive the support that is - or is not-offered to them and provide a better understanding of the strategies and skills that online teachers and on-site facilitators need to understand and develop in order to lower online course attrition rates. 


\section{References}

Anderson, T., Rourke, L., Garrison, D. R., \& Archer, W. (2001). Assessing teaching presence in a computer conferencing context. Journal of Asynchronous Learning Networks, 5(2), 117.

Archambault, L., Kennedy, K., Shelton, C., Dalal, M., McAllister, L., \& Huyett, S. (2016). Incremental progress: Re-examining field experiences in K-12 online learning contexts in the United States. Journal of Online Learning Research, 2(3), 303-326.

Barbour, M. K., \& Hill, J. (2011). What are they doing and how are they doing it? Rural student experiences in virtual schooling. Journal of Distance Education, 25(1). Retrieved from http://www.jofde.ca/index.php/jde/article/view/725/1248

Barbour, M. K., \& Mulcahy, D. (2004). The role of mediating teachers in Newfoundland's new model of distance education. The Morning Watch, 32(1). Retrieved from http://www.mun.ca/educ/faculty/mwatch/fall4/barbourmulcahy.htm

Barbour, M. K., \& Mulcahy, D. (2009). Beyond volunteerism and good will: Examining the commitment of school-based teachers to distance education. In Annual Conference of the Society for Information Technology and Teacher Education.

Borup, J. (2018). On-site and online facilitators: Current and future direction for research. In K. Kennedy and R. Ferdig (Eds.), Handbook of research on K-12 online and blended learning (2nd ed.). (pp. 423-442). ETC Press. Retrieved from: http://repository.cmu.edu/etcpress/82/

Borup, J., Graham, C. R., \& Drysdale, J. (2014). The nature of online teacher engagement at an online high school. British Journal of Educational Technology, 45, 793-806. doi: 10.1111/bjet.12089

Borup, J. \& Stevens, M. (2016a). Factors influencing teacher satisfaction at an online charter school. Journal of Online Learning Research, 2, 3-22.

Borup, J. \& Stevens, M. (2016b). Parents' perceptions of teacher support at a cyber charter high school. Journal of Online Learning Research. 2, 227-246. Retrieved from: http://www.learntechlib.org/p/173212

Borup, J. \& Stevens, M. (2017). Using student voice to examine teacher practices at a cyber charter high school. British Journal of Educational Technology, 48, 1119-1130.

Borup, J. \& Stimson, R. (2017). Helping online students be successful: Mentor responsibilities. Lansing, MI: Michigan Virtual Learning Research Institute. Retrieved from: http://media.mivu.org/institute/PDF/helping-students-mentors-responsibilities.pdf 
Borup, J. \& Stimson, R. (2019). Responsibilities of online teachers and on-site facilitators in online high school courses. American Journal of Distance Education. 33(1), 29-45. https://doi.org/10.1080/08923647.2019.1554984

Borup, J., West, R. E., Graham, C. R., \& Davies, R. S. (2014). The Adolescent Community of Engagement: A framework for research on adolescent online learning. Journal of Technology and Teacher Education, 22(1), 107-129.

Borup, J., West, R. E., \& Thomas, R. A. (2015). The impact of text versus video communication on instructor feedback in blended courses. Educational Technology Research and Development, 63, 161-184. doi :10.1007/s11423-015-9367-8

Borup, J., West, R. E., Thomas, R. A., Graham, C. R. (2014). Examining the impact of video feedback on instructor social presence in blended courses. The International Review of Research in Open and Distance Learning, 15, 232-256.

Cavanaugh, C. (2007). Student achievement in elementary and high school. In M. G. Moore (Ed.), Handbook of distance education (2nd ed., pp. 157-168). Mahwah, NJ: Lawrence Erlbaum Associates.

Dawson, K. \& Dana, N. F. (2018). Professional development for K-12 online teachers. In K. Kennedy and R. Ferdig (Eds.), Handbook of research on K-12 online and blended learning (2nd ed.). (pp. 247-260). ETC Press. Retrieved from: http://repository.cmu.edu/etcpress/82/

de la Varre, C., Irvin, M. J., Jordan, A. W., Hannum, W. H., \& Farmer, T. W. (2014). Reasons for student dropout in an online course in a rural K-12 setting. Distance Education, 35(3), 324-344. https://doi.org/10.1080/01587919.2015.955259

de la Varre, C., Keane, J., \& Irvin, M. J. (2011). Dual perspectives on the contribution of on-site facilitators to teaching presence in a blended learning environment. Journal of Distance Education, 25(3). Retrieved from http://www.jofde.ca/index.php/jde/article/viewArticle/751/1285

Drysdale, J. S., Graham, C. R., \& Borup, J. (2016). Teacher and student perspectives on facilitating a sense of community through an online high school's "shepherding" program. International Journal of E-Learning, 15(2), 149-178.

Eraut, M. (2006). Feedback. Learning in Health and Social Care, 5, 111-118. https://doi.org/doi:10.1111/j.1473-6861.2006.00129.x

Evergreen Educational Group. (2017). Keeping pace with K-12 online learning 2016. Evergreen Education Group. Retrieved from http://www.kpk12.com/wpcontent/uploads/EEG KP2016-web.pdf 
Freidhoff, J. R. (2018). Michigan's k-12 virtual learning effectiveness report: 2016-17. Lansing, MI: Michigan Virtual University. Available from: https://mvlri.org/research/effectiveness-report/

Freidhoff, J. R., Borup, J., Stimson, R. J., \& DeBruler, K. (2015). Documenting and sharing the work of successful on-site mentors. Journal of Online Learning Research, 1(1), 107-128.

Ferdig, R. E., Cavanaugh, C., DiPietro, M., Black, E., \& Dawson, K. (2009). Virtual schooling standards and best practices for teacher education. Journal of Technology and Teacher Education, 17(4), 479-503.

Garrison, R. (2009). Implications of online learning for the conceptual development and practice of distance education. Journal of Distance Education, 23(2), 93-104.

Garrison, D. R., Anderson, T., \& Archer, W. (2000). Critical inquiry in a text-based environment: Computer conferencing in higher education. The Internet and Higher Education, 2(2-3), 87-105. https://doi.org/10.1016/S1096-7516(00)00016-6

Glaser, B. G. (1965). The constant comparative method of qualitative analysis. Social Problems, 12(4), 436-445. Retrieved from http://www.jstor.org/stable/798843

Graham, C. R., Henrie, C. R., \& Gibbons, A. S. (2014). Developing models and theory for blended learning research. In A. G. Picciano, C. D. Dziuban, \& C. R. Graham (Eds.), Blended learning: Research perspectives, volume 2 (pp. 13-33). New York, NY: Taylor \& Francis.

Hannum, W. H., Irvin, M. J., Lei, P., \& Farmer, T. W. (2008). Effectiveness of using learnercentered principles on student retention in distance education courses in rural schools. Distance Education, 29(3), 211-229. https://doi.org/10.1080/01587910802395763

Harms, C. M., Niederhauser, D. S., Davis, N. E., Roblyer, M. D., \& Gilbert, S. B. (2006). Educating educators for virtual schooling: Communicating roles and responsibilities. The Electronic Journal of Communication, $16(1 \& 2)$.

Hattie, J. (2009). Visible learning: A synthesis of over 800 meta-analyses relating to achievement. Routledge, New York.

Hawkins, A., Barbour, M. K., \& Graham, C. R. (2011). Strictly business: Teacher perceptions of interaction in virtual schooling. The Journal of Distance Education, 25(2).

Hawkins, A., Barbour, M. K., \& Graham, C. R. (2012). "Everybody is their own island": Teacher disconnection in a virtual school. The International Review of Research in Open and Distance Learning, 13(2), 124-144. 
Hendrix, N., \& Degner, K. (2016). Supporting online AP students: The rural facilitator and considerations for training. American Journal of Distance Education, 30(3), 133-144. https://doi.org/10.1080/08923647.2016.1198194

Hillman, D. C., Willis, D. J., \& Gunawardena, C. (1994). Learner-interface interaction in distance education: An extension of contemporary models and strategies for practitioners. American Journal of Distance Education, 8(2), 30-42.

Irvin, M. J., Hannum, W. H., Farmer, T. W., de la Varre, C., \& Keane, J. (2009). Supporting online learning for advanced placement students in small rural schools: Conceptual foundations and intervention components of the facilitator preparation program. The Rural Educator, 31(1), 29-37.

Keane, J., de la Varre, C., Irvin, M. J., \& Hannum, W. (2008). Learner-centered social support: enhancing online distance education for underserved rural high school students in the United States. In N. Whitton \& M. McPherson (Eds.), Rethinking the Digital Divide: Research Proceedings of the 15th Association for Learning Technology Conference (ALT-C 2008) (pp. 39-48). Retrieved from http://repository.alt.ac.uk/435/1/ALT_C_2008_rp_keanej_delavarrec_irvinm_hannumw.p df

Kim, C., Park, S. W., \& Cozart, J. (2013). Affective and motivational factors of learning in online mathematics courses. British Journal of Educational Technology, n/a-n/a. https://doi.org/10.1111/j.1467-8535.2012.01382.x

Larkin, I. M., Brantley-Dias, L., \& Lokey-Vega, A. (2015). Job satisfaction, organizational commitment, and turnover intention of online teachers in the K-12 setting. Online Learning, 20(3), 26-52.

Lin, C., Zheng, B., \& Zhang, Y. (2017). Interactions and learning outcomes in online language courses. British Journal of Educational Technology, 48(3), 730-748. https://doi.org/10.1111/bjet.12457

Lowes, S., \& Lin, P. (2015). Learning to learn online: Using locus of control to help students become successful online learners. Journal of Online Learning Research, 1(1), 17-48.

Merriam, S. B. (1998). Qualitative research and case study applications in education: Revised and expanded from case study research in education. San Francisco, CA: Jossey-Bass.

Michigan Department of Education. (2014). 5-O-A: Virtual learning, distance learning, \& independent study. In Pupil accounting manual (pp. 5-O-A-1 - 5-O-A-5). Lansing, MI. Retrieved from http://mi.gov/documents/5O-VirtualHS-DistLearn- ing_41466_7.pdf

Michigan Public Act $\S$ No. 60. (2013). Retrieved from http://www.legislature.mi.gov/documents/2013-2014/publicact/htm/2013-PA-0060.htm 
Mishra, P., \& Koehler, M. J. (2006). Technological pedagogical content knowledge: A framework for teacher knowledge. Teachers College Record, 108(6), 1017-1054.

Moore, M. G. (1980). Independent study. In R. D. Boyd \& J. Apps (Eds.), Redefining the discipline of adult education (pp. 16-31). San Francisco, CA: Jossey Bass.

Moore, M. G. (2007). The theory of transactional distance. In M. G. Moore (Ed.), Handbook of distance education (2nd ed., pp. 89-105). Mahwah, NJ: Lawrence Earlbaum Associates.

Moore, M. G. (1993). Theory of transactional distance. In D. Keegan (Ed.), Theoretical principles of distance education (pp. 22-28). New York, NY: Routledge.

Murphy, E., \& Rodríguez-Manzanares, M. A. (2009). Teachers' perspectives on motivation in high school distance education. Journal of Distance Education, 23(3), 1-24.

O’Dwyer, L. M., Carey, R., \& Kleiman, G. (2007). A study of the effectiveness of the Louisiana algebra I online course. Journal of Research on Technology in Education, 39(3), 289306.

Oviatt, D. R., Graham, C. R., Borup, J., \& Davies, R. S. (2018). Online student use of a proximate community of engagement in an independent study program. Online Learning, 22(1), 223-251. https://doi.org/10.24059/olj.v22i1.1153

Rice, K. L. (2006). A comprehensive look at distance education in the K-12 context. Journal of Research on Technology in Education, 38(4), 425-449.

Rice, M. F., \& Carter, R. A. (2016). Online teacher work to support self-regulation of learning in students with disabilities at a fully online state virtual school. Online Learning, 20(4), $118-135$.

Roblyer, M. D., Davis, L., Mills, S. C., Marshall, J., \& Pape, L. (2008). Toward practical procedures for predicting and promoting success in virtual school students. American Journal of Distance Education, 22(2), 90-109.

Roblyer, M. D., Davis, L., Mills, S. C., Marshall, J., \& Pape, L. (2008). Toward practical procedures for predicting and promoting success in virtual school students. American Journal of Distance Education, 22(2), 90-109.

Roblyer, M. D., Freeman, J., Stabler, M., \& Schneidmiler, J. (2007). External evaluation of the Alabama ACCESS initiative phase 3 report. Eugene, OR: International Society for Technology in Education. Retrieved from http://accessdl.state.al.us/2006Evaluation.pdf

Rourke, L., Anderson, T., Garrison, D. R., \& Archer, W. (2001). Assessing social presence in asynchronous text-based computer conferencing. Journal of Distance Education, 14(2), 51-70. Retrieved from http://www.jofde.ca/index.php/jde/article/view/153/341 
Rose, R. M., Smith, A., Johnson, K., \& Glick, D. (2015). Ensuring equitable access in online and blended learning. In T. Clark \& M. K. Barbour (Eds.), Online, blended, and distance education in schools: Building successful programs (pp. 71-83). Sterling, VA: Stylus Publishing.

Stake, R. E. (2010). Qualitative research: Studying how things work. New York, NY: Guilford Press.

Staker, H. (2011). The rise of K-12 blended learning: Profiles of emerging models. Innosight Institute. Retrieved from http://www.christenseninstitute.org/wpcontent/uploads/2013/04/The-rise-of-K-12-blended-learning.emerging-models.pdf

Taylor, S., Clements, P., Heppen, J., Rickles, J., Sorensen, N., Walters, K., .. Micheiman, V. (2016). Getting back on track the role of in-person instructional support for students taking online credit recovery: Research brief 2. Washington, D.C.: American Institutes for Research. Retrieved from http://www.air.org/system/files/downloads/report/Role-ofIn-Person-Instructional-Support-Online-Credit-Recovery-Algebra-April-2016.pdf

Thomas, R. A., West, R. E., \& Borup, J. (2017). An analysis of instructor social presence in online text and asynchronous video feedback comments. Internet and Higher Education, $33,61-73$.

Velasquez, A., Graham, C. R., \& West, R. E. (2013). An investigation of practices and tools that enabled technology-mediated caring in an online high school. The International Review of Research in Open and Distance Learning, 14(5), 277-299. Retrieved from http://www.irrodl.org/index.php/irrodl/article/view/1465/2758

Velasquez, A., Graham, C. R., \& Osguthorpe, R. D. (2013). Caring in a technology-mediated online high school context. Distance Education, 34(1), 97-118. https://doi.org/10.1080/01587919.2013.770435

Weil, L. G., Fleming, S. M., Dumontheil, I., Kilford, E. J., Weil, R. S., Rees, G., ... Blakemore, S. (2013). The development of metacognitive ability in adolescence. Consciousness and Cognition, 22(1), 264-271. https://doi.org/10.1016/j.concog.2013.01.004

West, R., Jay, J., Armstrong, M., \& Borup, J. (2017). "Picturing them right in front of me": Guidelines for implementing video communication in online and blended learning. TechTrends, 61, 461-469. Accessible at http://rdcu.be/tRrA

Whetten, D. A. (1989). What constitutes a theoretical contribution? The Academy of Management Review, 14(4), 490-495. https://doi.org/10.2307/258554 